\title{
KAJIAN USAHATANI TANAMAN TOMAT TERHADAP PRODUKSI DAN PENDAPATAN PETANI, (Studi Kasus di Desa Golago Kusuma, Kecamatan Jailolo Timur, Kabupaten Halmahera Barat)
}

\author{
Arman Drakel \\ Staf Pengajar FAPERTA UMMU-Ternate, $\boldsymbol{e}$-mail: Arman_drakel@yahoo.com
}

\begin{abstract}
ABSTRAK
Penelitian ini bertujuan untuk mengetahui usahatani tanaman tomat terhadap produksi dan pendapatan petani di Desa Golago Kusuma, Kecamatan Jailolo Timur, Kabupaten Halmahera Barat. Metode yang dipakai pengambilan adalah Perpussive sampling atau sampel sederhana pada petani yang berjumlah 20 responden, semuanya dijadikan sampel. Hasil penelitian menunjukkan bahwa petani dalam berusahatani dipengaruhi oleh : a) umur petani responden antara 30 - 37 tahun atau usia muda sebesar $30 \%$, golongan umur $38-45$ tahun atau usia sedang sebesar $50 \%$ dan golongan umur $46-53$ tahun usia tua sebesar 20 $\%$, b) strata pendidikan petani terdiri dari SLTP $60 \%$ dan SLTP $40 \%$, c) jumlah tanggungan keluarga lebih sedikit $65 \%$ pada kisaran sedang $35 \%$ dari kisaran jumlah yang banyak sebesar $0 \%$, d) luas yang digunakan berkisar antara 0.10 meter persegi yaitu $95 \%$ dan luas lahan yang berkisar antara 0.25 meter persegi yaitu $5 \%$, e) pengalaman berusahatani berkisar antara $1-4$ tahun yaitu $20 \%$ dan antara $5-10$ tahun yaitu $80 \%$. Besarnya pendapatan satu kali produksi adalah $R$ p. 65.542.250,- dengan rata rata pendapatan yang diterima oleh masing masing petani adalah sebesar Rp. 3.277.113,-.
\end{abstract}

Kata Kunci: Usahatani, Produksi, Pendapatan

\section{PENDAHULUAN \\ 1.1.Latar Belakang}

Pengembangan usaha di sektor agribisnis usahatani merupakan salah satu ciri khas aktifitas ekonomi pertanian. Kegiatan ekonomi pertanian memiliki perencanaan secara terpadu baik hulu maupun hilir serta di dukung kekuatan struktur pasar yang kuat. Disisi lain kegiatan ekonomi pertanian perlu didukung kekuatan agroindustri di bidang pertanian yang tangguh dapat meningkatkan kekuatan ekonomi masyarakat (Soekartawi, 1990).

Dalam pengelolaan proses produksi usaha tani perlu didasari oleh suatu konsepsi perencanaan menejemen usaha tani untuk mengetahui besarnya sumberdaya yang dialokasi dengan karasteristik pasar yang memenuhi target produksi. Jika perencanaan dan alokasi sumberdaya dan akses mekanisme pasar tidak diperhitungkan, akan mempengaruhi target produksi dan pendapatan. Karena kegiatan usahatani memerlukan sumberdaya dan alokasi biaya, tanpa didukung kemampuan pengelolaan menejemen usahatani yang baik, akan menguras sumberdaya yang dialokasi. Dampak yang timbul adalah kerugian yang ada dan lama pemulihan kembali sumberdaya dalam kegiatan usahatani. Pengelolaan produksi usahatani harus dilakukan secara efektif dan efisien dengan tata kelola menejemen usahatani yang baik untuk meningkatkan produksi. Efisiensi produksi dapat dicapai dengan rencana dan proses produksi dengan benar dan meminimalisasi sumber sumber produksi yang menimbulkan pemborosan selama proses produksi berlangsung, baik pemborosan sumber daya, waktu dan tenaga dan kehilangan alat dan kerusakan produk (Soekartawi, 1999).

Perhatian dalam aspek produksi bagi petani produsen tanaman sayur mayur di pedesaan, harus merubah pola tanaman sayurmayur dengan konversi pola tanaman memakai bibit unggul yang mudah diperoleh para petani atau produsen, terutama tersedia bibit unggul tanaman. 
Sebagai fungsi sumber zat gizi dan pangan untuk pemenuhan kebutuhan masyarakat, tanaman semusim dalam rentangan waktu tanam sampai panen memerlukan waktu yang pendek, sehingga diharapkan menjaga kestabilan produksi dan besarnya volume produksi. untuk memenuhi kebutuhan manusia (Hernanto, 1996).

Usahatani tanaman semusim diperlukan untuk memenuhi kebutuhan pangan nabati, juga memiliki nilai manfaat produksi yang melibatkan banyak kehidupan petani dan keluarga di pedesaan.

Tanaman tomat (Lycopersicum esculentum, Mill) merupakan salah satu tanaman semusim dengan sifat pertumbuhannya adalah tanaman perdu atau semak dan merupakan tanaman yang nilai ekonomis cukup tinggi.banyak di konsumsi masyarakat. Tanaman ini memiliki nilai ekonomi pasar dengan stabilitas harga yang memadai. Dengan rasio kebutuhan konsumsi tomat tidak sebanding dengan produksi usahatani, perlu dilakukan kebijakan import tomat yang dilakukan oleh pemerintah Propinsi Maluku Utara untuk memenuhi kebutuhan pasar dan konsumsi masyarakat. Disamping buah tomat sebagai tanaman bergizi, permintaan tomat ditingkat pasaran terus meningkat sejalan dengan pertumbuhan ekonomi pasar, pertumbuhan jumlah penduduk, pendapatan masyarakat dan harga yang stabil. Dengan pertumbuhan ekonomi sebesar $6 \%$ - 7\% dan pertumbuhan penduduk $2,1 \%$ disertai dengan pertumbuhan pendapatan masyarakat, maka kebutuhan tomat di pasaran akan meningkat cukup besar, baik untuk keperluan makanan, pengobatan ataupun lainnya (Rukmana, 1994).

Data Badan Pusat Statistik (BPS) Kabupaten Halmahera Barat 2011 menunjukkan perkembangan produksi tomat dari tahun 20072011 dapat dilihat pada Tabel 1.

Tabel 1. Perkembangan Produksi Tomat Tahun 2007-2011 di Kabupaten Halmahera Barat

\begin{tabular}{cccc}
\hline Tahun & $\begin{array}{c}\text { Luas Panen } \\
\text { (Ha) }\end{array}$ & $\begin{array}{c}\text { Produksi } \\
\text { (Ton) }\end{array}$ & $\begin{array}{c}\text { Produktivitas } \\
\text { (Ton/Ha) }\end{array}$ \\
\hline 2007 & 11 & 41,23 & 4,95 \\
2008 & 12,03 & 42,19 & 5,72 \\
2009 & 12,97 & 42,93 & 5,98 \\
2010 & 13,51 & 43,76 & 6,08 \\
2011 & 13,87 & 43,86 & 6,73 \\
\hline \multicolumn{4}{l}{ Sumber : BPS Kabupaten Halmahera Barat, 2007-2011 }
\end{tabular}


Kecamatan Jailolo Timur, Kabupaten Halmahera Barat.

\subsection{Tujuan Penelitian}

Penelitian ini bertujuan untuk Mengetahui usahatani tanaman tomat dapat mempengaruhi produksi dan pendapatan masyarakat petani di Desa Golago Kusuma, Kecamatan Jailolo Timur, Kabupaten Halmahera Barat.

\section{METODE PENELITIAN}

\subsection{Tempat Dan Waktu Penelitian}

Tempat penelitian ini adalah di Desa Golago Kusuma Trans Goal Kecamatan Jailolo Selatan, Kabupaten Halmahera Barat pada bulan Juni sampai dengan Juli 2011. Lokasi ini dipilih karena merupakan salah satu sentra produksi tanaman tomat.

\subsection{Jenis Dan Sumber Data}

Adapun jenis data yang digunakan dalam penelitian ini adalah data primer dan data sekunder.

1. Data primer adalah data yang di peroleh langsung dari masyarakat petani di Trans Goal Kecamatan Jailolo Timur. Data ini diambil terlebih dahulu dilakukan observasi untuk mengetahui jumlah petani menanam tomat. Dan data selanjutnya diambil adalah dilakukan wawancara dengan petani dengan menggunakan quisioner yang dibuat sebelumnya berdasarkan jumlah sampel yang ditetapkan. Tahapan dalam mengambilan data ini adalah setelah diambil dikumpulkan dan selanjutnya dibuat tabulasi dan dianalisis data.

2. Data sekunder berupa data yang bersumber dari berbagai referensi yang berhubungan dengan variabel penelitian ini. Data ini di peroleh dari instansi terkait berdasarkan penetapan criteria data baik internet, referensi lainnya.

\subsection{Metode Pengambilan Sampel}

Penelitian ini menggunakan metode sensus. Sensus adalah sebuah proses mendapatkan informasi tentang anggota sebuah populasi. Untuk pengambilan sampel menggunakan metode secara sengaja (purposive sampling) pada masyarakat usahatani tanaman tomat di Trans Goal. Dengan pertimbangan masyarakat usahatani semuanya menanam tanaman tomat dan sampel yang disampling adalah 20 petani yang dijadikan sampel.

\subsection{Metode Analisis Data}

Penelitian ini dianalisis secara kuantitatif dengan menggunakan metode statistik deskriptif yaitu menjelaskan data dalam ukuran-ukuran nilai angka yang dapat menggambarkan karakteristik data, antara lain :

\subsubsection{Analisis Biaya}

Untuk mengetahui seberapa besar biaya produksi yang dikeluarkan masyarakat petani tomat perlu dilakukan perhitungan biaya yang dikeluarkan untuk masing-masing input. Untuk mengetahui total biaya yang dikeluarkan tersebut secara matematis dapat dihitung dengan memakai rumus :

$$
\mathbf{T C}=\mathbf{T F C}+\mathbf{T V C}
$$

Dimana :

$$
\begin{aligned}
\text { TC } & =\text { Total Cost (Total Biaya) } \\
\text { TVC } & =\text { Total Variabel Cost (Total Biaya } \\
& \text { Variabel) } \\
\text { TFC } & =\text { Total Fixed Cost (Total Biaya Tetap) }
\end{aligned}
$$

\subsubsection{Analisis Pendapatan}

Untuk menganalisis aspek usahatani dari komoditi tomat yang dikelola oleh masyarakat usatani di Trans Goal Kecamatan Jailolo Timur, terlebih dahulu dianalisis tingkat pendapatan usahatani tomat dengan formula yang dikemukan oleh (Mosher, 1998), sebagai berikut :

Rumus total penerimaan dan total pengeluaran di peroleh dengan formula :

$$
\mathbf{T R}=\mathbf{P} \text { X Q }
$$

Dimana :

$\mathrm{TR}=$ Total Revenue (Total penerimaan)

$\mathrm{Q}=$ Jumlah Produk

$\mathrm{P}=$ Harga Jual Produk

Rumus total pendapatan yang diterima oleh petani responden dengan formula :

$$
\mathbf{N R}=\mathbf{T R}-\mathbf{T C}
$$

Dimana :

NR $=$ Net Riturn (Pendapatan Bersih)

$\mathrm{TR}=$ Total Revenue (Total Penerimaan)

$\mathrm{TC}=$ Total Cost (Total Pengeluaran)

\section{HASIL DAN PEMBAHASAN \\ 3.1. Karakteristik Responden Dan Sarana \\ Produksi Usahatani Tomat}

Identitas petani responden meliputi umur, tingkat pendidikan, pengalaman berusahatani, jumlah tanggungan keluarga dan jumlah keluarga yang ikut membantu dalam usahatani atau tenaga kerja dalam keluarga. 


\subsubsection{Umur Petani Responden}

Faktor umur akan mempengaruhi tenaga kerja dan cara berpikir petani, cara berpikir logis hingga dapat menyelesaikan masalah. Bagi petani usia tua pengalaman yang didapat turun temurun masih menjadi andalan dalam bercocok tanam sehingga sering mereka tidak dapat menerima berbagai metode yang diterapkan atau dianjurkan oleh pemerintah karena dianggap bertentangan seperti yang dilihat pada Tabel 2 .

Tabel 2. Jumlah Petani Responden Menurut Kelompok Umur pada Masyarakat Tani di Trans Goal Kecamatan Jailolo, Halbar Tahun 2011.

\begin{tabular}{|ccc|}
\hline \multicolumn{1}{c}{ Umur petani } & $\begin{array}{c}\text { Jumlah } \\
\text { Petani }\end{array}$ & $\begin{array}{c}\text { Presentase } \\
(\%)\end{array}$ \\
\hline $30-37$ (muda) & 6 & 30 \\
$38-45$ (sedang) & 10 & 50 \\
$46-53$ (tua) & 4 & 20 \\
\hline \multicolumn{1}{c}{ Jumlah } & 20 & 100 \\
\hline
\end{tabular}

Sumber: Data primer (2011)

Data Tabel 2 menunjukkan sebagian besar petani yang termasuk golongan usia $30-37$ tahun sebesar $30 \%$, golongan usia $38-45$ tahun sebesar $50 \%$, dan petani yang termasuk dalam golongan usia tua mencapai $20 \%$. Hal ini berarti sebagian besar petani responden dapat menerima berbagai metode yang diterapkan atau dianjurkan oleh pemerintah.

\subsubsection{Tingkat Pendidikan Petani}

Tingkat pendidikan seorang petani turut memberikan pengaruh terhadap pengelolaan usahatani. Semakin tinggi tingkat pendidikan petani diharapkan semakin mudah proses adopsi, inovasi-inovasi baru baik dalam implementasi teknik budidaya yang baik, penanganan pasca panen usahataninya. Strata pendidikan petani responden masyarakat petani di Trans Goal, Kecamatan Jailolo Timur menunjukkan tingkat pendidikan petani responden beragam. Tingkat pendidikan SLTA sebesar $60 \%$ Dan SLTP sebesar $40 \%$. Hal ini juga berarti sebesar $60 \%$ petani berpendidikan tinggi, sehingga akan semakin mudah proses adopsi dan inovasi dalam usahataninya.

\subsubsection{Jumlah Tanggungan Keluarga}

Jumlah tanggungan keluarga responden terdiri dari petani itu sendiri, istri, anak dan anggota keluarga lainnya yang menjadi tanggungan petani. Data jumlah tanggungan keluarga petani terdapat kisaran $1-3$ atau sedikit sebesar $65 \%$, pada kisaran $4-6$ atau sedang sebesar $35 \%$, dan pada kisaran $\geq 7$ atau banyak sebesar $0 \%$. Hal ini berarti sebagian anggota keluarga petani dapat merupakan sumber tenaga kerja dalam kegiatan usahatani terutama anggota yang produktif.

\subsubsection{Luas Lahan Usahatani}

Lahan yang dikelola petani akan mempengaruhi dalam usahatani serta produksi dan pendapatan yang diperoleh petani, Luas lahan yang dimiliki masyarakat petani di Trans Goal adalah 3 hektar tetapi luas lahan yang digunakan masing-masing petani berbeda, yaitu antara $0,10 \mathrm{Ha}$ dan $0,25 \mathrm{Ha}$. Lebih jelasnya dapat dilihat pada Tabel 3 .

Tabel 3. Jumlah Luas Lahan Masyarakat Petani di Trans Goal Kecamatan Jailolo Timur Tahun 2011.

\begin{tabular}{cccc}
\hline No & $\begin{array}{c}\text { Luas Lahan } \\
\left(\mathbf{M}^{2}\right)\end{array}$ & Jumlah Petani & $\begin{array}{c}\text { Presntase } \\
(\%)\end{array}$ \\
\hline 1 & 0,25 & 19 & 95 \\
2 & 0,10 & 1 & 5 \\
\hline & Jumlah & $\mathbf{2 0}$ & $\mathbf{1 0 0}$ \\
\hline
\end{tabular}

Sumber : Data primer (2011)

Data Tabel 3 menunjukkan luas lahan yang berkisar antara 0,10 yaitu 19 orang atau $95 \%$, dan luas lahan yang berkisar $0,25 \mathrm{M}^{2}$ yaitu 1 orang atau $5 \%$. Hal ini berarti semakin luas lahan garapan, semakin besar produksi yang dihasilkan.

\subsubsection{Pengalaman Berusahatani}

Pengalaman berusahatani dapat mempengaruhi kegiatan usahataninya, karena pengalaman petani sangat berperan dalam mengambil suatu keputusan. Data pengalaman petani responden dalam berusahatani tanaman berbeda, dimana jumlah presentase pengalaman berusahatani yang berkisar antara $1-4$ adalah 4 orang atau $20 \%$, dan berkisar antara $5-10$ adalah 16 orang atau $80 \%$. Hal ini berarti karena pengalaman petani sangat berperan dalam mengambil suatu keputusan.

\subsection{Penggunaan Sarana Produksi}

Sarana produksi yang digunakan dalam usahatani tanaman tomat yaitu benih, pupuk, obat-obatan dan penggunaan tenaga kerja. Dengan tersedianya sarana produksi yang dimiliki petani responden tersebut diharapkan dapat meningkatkan produksi usahatani itu sendiri. Oleh karena ituhasil produksi yang diperoleh petani responden sangat bervariasi tergantung dari penggunaan sarana produksi. 


\subsubsection{Penggunaan Benih atau Bibit}

Penggunaan benih berdasarkan jumlah dan kualitas yang baik dengan metode yang dianjurkan sangat mempengaruhi produksi baik secara kualitas maupun kuantitas. Benih yang digunakan oleh petani responden berasal dari benih varietas unggul.

Data penggunaan benih oleh petani jumlahnya 20 Gram adalah 18 petani, penggunaan benih yang jumlah 40 Gram adalah 1 petani, dan penggunaan benih yang jumlah 60 Gram adalah 1 petani.

\subsubsection{Penggunaan Pupuk}

Pupuk adalah suatu bahan yang digunakan untuk memperbaiki kesuburan tanah dan meningkatkan unsur hara dalam meningkatkan produksi tanaman. Penggunaan pupuk harus sesuai dosis atau anjuran yang diberikan. Harga masing-masing pupuk berbeda tergantung dengan jenis pupuk. Data penggunaan pupuk pada usahatani tanaman tomat rata-rata untuk pupuk kandang sebesar $810 \mathrm{Kg}$, pupuk Urea sebesar 280 $\mathrm{Kg}, \mathrm{KCl}$ sebesar $126 \mathrm{Kg}$ dan NPK sebesar $86 \mathrm{Kg}$.

\subsubsection{Penggunaan Pestisida}

Penggunaan pestisida untuk tanaman tomat sangat berguna dalam pengendalian atau pemberantasan hama dan penyakit tanaman. Data penggunaan pestisida oleh masyarakat petani Trans Goal yaitu Dursban 250 cc, Decis $245 \mathrm{ml}$ dan Dithane $160 \mathrm{ml}$. Obat-obatan tersebut merupakan kebiasaan bagi petani untuk tanaman

\subsubsection{Penggunaan Tenaga Kerja}

Untuk diketahui bahwa jumlah tenaga kerja yang digunakan adalah tenaga kerja yang berasal dari keluarga sendiri. Tanggungan keluarga yaitu jumlah anggota keluarga petani akan berpengaruh bagi petani dalam perencanaan dan pengambilan keputusan petani dalam hal usahataninya. Data presentase jumlah tenaga kerja berkisar antara 1 - 3 yaitu 55\% dan presentase jumlah tenaga kerja yang berkisar antara 4 - 6 yaitu $45 \%$.

\subsection{Analisis Biaya Dan Pendapatan}

Defenisi biaya adalah korbanan yang digunakan dalam proses untuk mendapatkan pendapatan yang menrupakan biaya yang telah dipakai (exired cost) atau beban. Jenis biaya ini sepserti biaya variabel dan biaya tetap.

Biaya variabel adalah biaya yang jumlah totalnya berubah sesuai dengan perubahan volume produksi. Semakin besar volume produksi semakin pula jumlah total biaya variabel yang dikeluarkan. Sebaliknya semakin kecil volume produksi semakin kecil pula jumlah total biaya variabel (Hernanto, 1996).

Biaya tetap adalah biaya yang jumlah totalnya konstan tidak dipengaruhi perubahan volume produksi pada periode tertentu. Semakin tinggi volume produksi semakin rendah baiaya satuannya sebaliknya semakin rendah volume produksi semakin besar biaya satuannya. Pendapatan bersih atau keuntungan yang diperoleh adalah selisih antara penerimaan total biaya dan biaya yang dikeluarkan (Soekartawi, 1990).

Pendapatan dapat dibedakan menjadi dua yaitu : pendapatan kotor dan pendapatan bersih, pendapatan kotor adalah total penerimaan dari pemakaian sumber daya dalam proses produksi atau dengan kata lain pendapat kotor merupakan nilai semua produksi. Pendapatan bersih merupakan selisih antara pendapatan kotor dengan total biaya, pendapat bersih berarti juga sebagai keuntungan (Kadarusman, 2003). Untuk mengetahui hasil analisis biaya dalam proses produksi dan pendapatan dapat dilihat pada Tabel 4.

Tabel 4. Hasil Analisis Biaya dan Pendapatan Musin Tanam 2011 Masyarakat Tani di Trans Goal Kecamatan Jailolo Timur 2011.

\begin{tabular}{clcc}
\hline No & \multicolumn{1}{c}{ Uraian } & \multicolumn{1}{c}{ Jumlah } & Rata-rata \\
\hline 1 & $\begin{array}{l}\text { Biaya Variabel } \\
\text { (TVC) }\end{array}$ & Rp.4.729.000 & 236.450 \\
& $\begin{array}{l}\text { Biaya Tetap } \\
\text { (TFC) }\end{array}$ & Rp.1.168.750 & 58.438 \\
3 & $\begin{array}{l}\text { Total Biaya (TC) } \\
\text { Rp. } 5.897 .750\end{array}$ & 294.888 \\
4 & $\begin{array}{l}\text { Total produksi } \\
\text { (Q) }\end{array}$ & 23.815 (lkat) & 11.908 (ikat) \\
5 & $\begin{array}{l}\text { Harga Jual } \\
\text { produk (P) }\end{array}$ & Rp.3.000/ikat & 3.000 \\
6 & $\begin{array}{l}\text { Total } \\
\text { Penerimaan (TR) }\end{array}$ & Rp.71.440.000 & 3.572 .000 \\
7 & $\begin{array}{l}\text { Pendapatan } \\
\text { (NR) }\end{array}$ & Rp.65.542.250 & 3.277 .113 \\
\hline Sumber: Data primer(2011) & &
\end{tabular}

Sumber: Data primer(2011)

Data Tabel 4, menunjukkan bahwa biaya tetap yang dikeluarkan oleh petani responden dengan nilai rata-rata sebesar Rp.58.438, sedangkan biaya variabel dengan nilai rata-rata sebesar Rp.236.450, dan total biaya pengeluaran petani responden dengan nilai rata-rata sebesar Rp.294.888, sedangkan total penerimaan yang diperoleh petani responden dengan nilai rata-rata sebesar Rp.3.572.000, serta tingkat pendapatan yang di terima oleh petani responden dengan nilai rata-rata sebesar Rp.3.277.113. Hal ini menunjukkan bahwa usahatani tanaman tomat 
menguntungkan karena pendapatan lebih tinggi dibandingkan dengan total biaya yang dikeluarkan oleh petani responden.

\section{KESIMPULAN DAN SARAN \\ 4.1. Kesimpulan}

Dari pembahasan hasil penelitian yang ada dapat ditarik kesimpulan bahwa Hasil analisis biaya produksi dan pendapatan usahatani dalam satu kali produksi adalah Rp.65.542.250 dengan rata-rata pendapatan masing-masing petani responden Rp.3.277.113. sehingga kegiatan usahatani tanaman tomat sangat menguntungkan.

\subsection{Saran}

Berdasarkan hasil penelitian yang dilakukan dapat disarankan sebagai berikut :

1. Agar dapat meningkatkan hasil produksi tanaman tomat, diperlukan partisipasi aktif dalam kegiatan penyuluhan pertanian.

2. Kepada pemerintah daerah setempat agar menyediakan lahan yang paten untuk petani dalam berusahatani dan sekaligus suntikan dana usaha tani secara bergilir.

\section{DAFTAR PUSTAKA}

Badan Pusat Statistik (BPS), 2011, Kabupaten Halmahera Barat Dalam Angka

Firdaus M. (2008), Menejemen Agribisnis, PT. Bumi Aksara Jakarta

Hermanto, 1996, Ilmu Usahatani, Penebar Swadaya, Jakarta

Kadarusman, 2003, Teori Ekonomi Mikro, Swadaya Jakarta

Rukmana, 1994, Budidaya dan Pengaturan Panen Sayuran Dataran Rendah, Penebar Swadaya, Jakarta

Mosher, 1998, Menggerakkan dan Membangun Pertanian, Yasaguna, Jakarta

Soeharto, 2006, Ekonomi Menejeral, Andi, Yogyakarta

Soekirno Sadono, 2000, Ekonomi Makro, Raja Grafindo Persada, Jakarta

Soekartawi, 1990, Teori Ekonomi Produksi Pertanian, Rajawali Persada, Jakarta

Soekartawi, 1999, Menejemen Pemasaran Hasil-Hasil Pertanian, Rajawali Grafindo Persada, Malang

Soekartawi, 2003, Teori Ekonomi Produksi Pertanian, Rajawali Persada, Jakarta

Soekartawi, 2005, Teori Ekonomi Produksi, dengan pokok bahasan Analisis Fungsi Cobb Douglas, Rajawali Press Jakarta.

Soewito, M, 1987, Bercocok Tanam Tanaman Tomat, CV. Titik Terang, Jakarta

Tugiyono H. 1996, Bertanam Tomat, PT. Penebar Swadaya, Jakarta 